\title{
STONING AS PUNISHMENT OF ZINA: IS IT VALID?
}

\author{
Mohammad Hashim Kamali*
}

\begin{abstract}
Three issues are explored in this article with regard to death by stoning as a punishment for adultery. First is its total absence in the Qur'an; the Qur'an makes no reference to stoning, providing a punishment of one hundred lashes of the whip for all adulterers, without any further qualification. Stoning as a punishment originates in the Sunnah of the Prophet, who applied it in the case of married adulterers, thus seemingly reserving the Qur'anic punishment for the unmarried adulterer. This perspective has dominated legal practice ever since. The second issue arising is as to how the conflicting rulings in the Qur'an and Sunnah relate to one another. Is it a case of specification (takhsis) or of abrogation (naskh)? If the latter, is it in order for the Sunnah to abrogate the Qur'an? The third issue is over the chronological sequence of the two rulings. If it is accepted that the Qur'anic ruling was revealed in Madinah after the few cases in which the Prophet applied stoning, then the Qur'an would have effectively overruled/abrogated the Prophetic practice. It is also said that the Prophet applied stoning by reference to the Torah, which was then set aside by the Qur'an. A minority opinion has also held that the Prophet applied stoning by way of ta'zir. A number of prominent twentieth-century shariah scholars have advised against the enforcement of stoning altogether.
\end{abstract}

Keywords: Qur'an, Sunnah, stoning, abrogation, ta'zir, modern opinion.

Zina in shariah is inclusive of adultery and fornication. The latter refers to consensual sexual intercourse between unmarried adults, whereas adultery is extramarital sex. Zina is defined as illicit sexual intercourse outside of marriage between a man and a woman while both know that they are prohibited to one another. Initially the Qur'an penalised adultery with imprisonment and detention of the accused women in their houses "until death came to them, or God ordained for them some other way," (sura al-Nisa', 4:15) provided that the charge was proven by the testimony of four upright witnesses. This was taken to mean a temporary measure awaiting a more definite pronouncement, which subsequently came in sura al-Nur (24:2), which determined one hundred lashes of the whip for both parties as standard Qur'anic punishment for the offence. In both of these two separate verses, the emphasis on repentance and reform is clearly articulated. Later it was claimed that the second of these punishments (of 100 
lashes) was abrogated in respect of married persons by the Sunnah of the Prophet, who ordered stoning to death (rajm) for a married adulterer. This meant that the Qur'anic 100 lashes remained applicable only to unmarried adulterers. A general consensus (ijma') was also claimed, although disputed by many, for this instance of partial abrogation of the Qur'an by the Sunnah. ${ }^{1}$

The Qur'an makes no reference to stoning, and the hadith that imposes this punishment is open to many questions. Yet the majority (jumhur) of Muslim jurists have upheld stoning for zina by a married person (muhsan), restricting the Qur'anic one hundred lashes to unmarried persons. The variant opinion on this subject, as elaborated below, maintains that the Qur'anic punishment of one hundred lashes applies to everyone, married and unmarried alike. This article ascertains the veracity of these views by looking at the evidential bases of each in the Qur'an, Sunnah and fiqh. This is then followed by a round-up of modern opinion on the subject among prominent shariah scholars, and a conclusion. We begin with a review of the Qur'anic verses.

The principal Qur'anic verse on zina and slanderous accusations of zina provides:

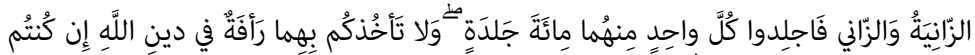

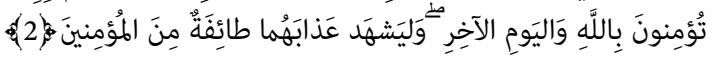

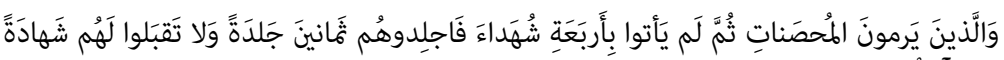

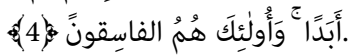

2. The adulterer and adulteress, flog each of them a hundred lashes. Let not compassion move you in their case from carrying out God's law, if you believe in God and the Last Day. And let a party of the believers witness their punishment...

4. And those who lay a charge against a chaste woman, and produce not four witnesses (to prove it) flog them with eighty lashes, and do not admit them to be witnesses ever again, for they are evildoers - unless they repent thereafter and correct themselves. For God is Forgiving, most Merciful. (Sura al-Nur, 24: 2-5)

The majority position, as well as that of the Shia Imamiyah, upholds that the Prophet implemented stoning for zina during his ten-year rule in Madinah. They add that the available hadith on stoning specify the general of the Qur'an; the 100 lashes are thus applied generally, which has then been specified with regard to married persons. ${ }^{2}$ Qur'an commentators understand the phrase "let 
not compassion move you in their case" to mean that the punishment in their case should not be postponed nor reduced in severity on grounds of compassion. This interpretation is attributed to three Successors (tabi'in), namely Mujahid, 'Ikrimah, and Sa'id bin Jubayr. According to another interpretation, since the verse makes no reference to married or unmarried persons as such, the 100 lashes therein apply to all without any distinction. ${ }^{3}$

The majority view elaborates that the Prophet applied stoning in the widely reported cases of Ma'iz b. Malik al-Aslami and al-Ghamidiyyah, as reported by the Companion Abu Hurayrah. It is then added that the Pious Caliphs also applied stoning; their precedent is generally seen as conclusive evidence on the continued validity of this punishment. We look at the reported details of these cases as follows.

Ma'iz belonged to the Aslam tribe and was an orphan. He was brought up by Hazal bin Na'im, and it was in Hazal's house that Ma'iz committed adultery with a freed slave girl. Upon learning this, Hazal, who did not know about the punishment of stoning, as the report says, sent Ma'iz to the Prophet. He instructed Ma'iz to admit to his guilt before the Prophet and request him to pray for the atonement of his sin. Ma'iz came to the Prophet and said: "Purify me for I have committed adultery." The Prophet turned his face away from Ma'iz and told him to go away and repent. Ma'iz repeated what he had said twice, but the Prophet avoided answering him on both occasions. Abu Bakr (later caliph) who was also present reminded Ma'iz that if he repeated it for the fourth time, the Prophet would have to order him stoned. But Ma'iz repeated the same for the fourth time. The Prophet then inquired about minute factual details. He inquired whether Ma'iz might have been drunk, which he denied. Then the Prophet inquired from the people of his tribe over the sanity of Ma'iz. Finally, the Prophet addressed Hazal with this remark, "I wish you had pulled a curtain over it," and ordered the stoning of Ma'iz. ${ }^{4}$

The variant view that questions the validity of stoning is based on the observation that the Qur'an is totally silent on stoning; had God Most High intended to validate stoning as a punishment, surely the Qur'an would make reference to it. This view has also questioned the evidence in the Sunnah by saying that the reported instances of stoning actually took place prior to the revelation of sura al-Nur (24:2-5), which prescribes 100 lashes as the only punishment for zina. If this is accepted, it would mean that the Qur'an overruled and abrogated stoning. It is further argued that the evidence in the Sunnah is only in the form of solitary ( $\mathrm{ahad}$ ) hadith. The fact that there is inconsistency in the contents of these hadith reports only aggravates the situation further.

It is further stated that some of the hadith reports on al-Ghamidiyyah contain a reference to banishment (al-taghrib) as a supplementary punishment to stoning, 
although this element is absent in other hadith reports concerning this case. There is a similar discrepancy in other hadith concerning the question of combining stoning with flogging. In some reports, flogging is held to be supplementary to stoning, whereas other hadith reports mention stoning as the only punishment, without reference to flogging. The Maliki and Shia schools have also upheld banishment for a year as a supplementary punishment, but while applying it only to men, as banishment for women could expose them to corruption. The other schools require that women be accompanied by a male relative (mahram).

In a chapter entitled "stoning for zina by a muhsan, and flogging for a nonmuhsan," al-Shawkani (d.1839) has recorded six hadith reports in Nayl al-Awtar, in which the following is observed: ${ }^{5}$

1. In the hadith of al-'Asif (lit. employee or servant) an unmarried young man committed zina with a married woman who had employed him. The hadith provides further details to the effect that the Prophet sentenced al-'Asif to 100 lashes and banishment of one year, while the woman was convicted to stoning only. The case has been reported in all Six Collections of hadith. The substance of this hadith, in so far as it concerns the woman, has also been confirmed by the hadith of Ma'iz. The conclusion has therefore been drawn that the Prophet did not combine lashing and stoning.

2. According to a hadith al-Bukhari recorded on the authority of Abu Hurayrah, the Prophet determined the punishment of zina by an unmarried person to be one hundred lashes and banishment for one year.

$$
\text { وعن أبي هريرة (رضى) أن النبي (ص) قضى في من زنا وم يحصن بنفي عام وإقامة الحد عليه }
$$

3. The hadith of 'Ubadah b. al-Samit, in which the Prophet declared: "Take it from me, take it from me: Allah has opened a way for them. The unmarried and virgin are liable to one hundred lashes and banishment for a year. For a married person the punishment is one hundred lashes and stoning."

$$
\text { خذائة والرجي خذوا عني قد جعل الله لهن سبيلا : البكر جلد مائة ونفي سنة , والثيب بالثيب ,جلد }
$$

Except for al-Bukhari and al-Nasa'i, this hadith has been recorded in the rest of the Six Hadith collections. Al-Zayla'i records that this is probably one of the earliest hadiths on the subject. ${ }^{6}$ This hadith is apparently in conflict with the hadith of al-"Asif, cited above, and also the hadith of Ma'iz in which the punishment of a married person was confined to stoning only, without flogging. Al-Sarakhsi has stated the Hanafi 
position, which is also that of the majority: that stoning and flogging may not be combined together because flogging a person who is sentenced to stoning seems superfluous and does not serve any good purpose. ${ }^{7}$ The leading schools of law have maintained that the Prophet never combined the two punishments of stoning and flogging. ${ }^{8}$ But unlike the majority, who combine flogging with banishment, the Hanafis do not accept this combination either.

4. The hadith of Jabir b. Samurah to the effect that "the Prophet ordered that Ma'iz b. Malik be stoned to death but did not mention flogging."

Al-Shawkani wrote concerning this hadith that, notwithstanding the fact that only Imam Ibn Hanbal and al-Nasa'i reported it, "its transmitters are reliable."

5. The report from al-Sha'bi, recorded by al-Bukhari and Ahmad b. Hanbal, to the effect that the fourth caliph, 'Ali b. Abu Talib, applied the prescribed punishment of zina on a married woman by the name Sharahah al-Hamadaniyyah consisting of both stoning and flogging. She was flogged on a Thursday and stoned on the Friday, and the Caliph is reported to have said "I flogged her in accordance with the Book of God and stoned her in accordance with the Sunnah of the Prophet." This is once again inconsistent with the hadith of both al-"Asif and Ma'iz, in which flogging was not applied in combination with stoning. A further inconsistency here is that al-Bukhari (Kitab al-Muharibun, Bab Rajm alMuhsan) has recorded only a shorter version of this hadith, in which there is no mention of flogging. According to this version, Caliph 'Ali only said "I stoned her in accordance with the Sunnah of the Prophet."

6. The hadith of Jabir b. 'Abd Allah, reported by Abu Dawud, that "a man committed zina with a woman and the Prophet applied the prescribed punishment on him. Then he was informed that the man was a muhsan, upon receiving this information the Prophet sentenced him to stoning and he was stoned".

Al-Shawkani has also recorded the hadith of Sahl b. Sa'd, to the effect that the Prophet flogged but did not banish an unmarried man from the tribe of Bakar who confessed to having committed zina. ${ }^{10}$

The Hanafi jurist al-Zayla'i wrote that the hadith of 'Ubadah b. al-Samit (no. 3 above) has been abrogated, explaining this by stating that initially the punishment for zina was unspecified, but could be any painful act (al-idha'). 
Then it became incarceration, as prescribed in the two verses of sura al-Nisa 4:1516, where it states fa-adhuhuma (punish/annoy them both) and famsikuhunnna fi'l buyut (detain the women in their houses) respectively. These portions of the Qur'an were subsequently abrogated by the hadith of 'Ubadah b. al-Samit, which fixed the punishment of an unmarried person at one hundred lashes and banishment for one year, and that of the married person at flogging and stoning. But all this happened, al-Zayla'i adds, before the revelation of sura al-Nur, as has been indicated in the hadith of 'Ubadah b. al-Samit, which began with the words khudhu 'anni (take it from me). Had the Prophet uttered this hadith after sura al-Nur, he would most likely have said khudhu 'an Allah (take it from God). The hadith of 'Ubadah was thus abrogated by sura al-Nur, which established flogging of one hundred lashes as the only punishment for all cases of zina. But then, al-Zayla'i further adds, this verse was also partially abrogated in regards to a married person by the application of stoning to Ma'iz and al-Ghamidiyyah. ${ }^{11}$

There is further information, however, which casts doubt upon the timings of the punishments metered out to Ma'iz and al-Ghamidiyyah. The relevant report recorded by al-Bukhari has it that a Companion, Ibn Abi Awfa', was asked by one al-Shaybani, who was a Follower (tabi' $i$ ): "Did the Prophet apply the punishment of stoning?" Abi Awfa' said "Yes." He was then asked whether this was before the revelation of sura al-Nur or after, to which he replied "I do not know." This raises doubts as to whether the ahadith which validated stoning and the actual cases in which stoning was implemented preceded the revelation of sura al-Nur, and so whether they were consequently abrogated by it. That prior to this event the Prophet might have simply applied stoning by reference to the ruling of the Torah is therefore possible. ${ }^{12}$

Even al-Zayla'i, who considered the hadith of al-Ghamidiyyah to have partially abrogated the Qur'anic verse in sura al-Nur, recorded two variant versions of that hadith, one of which is explicit to the effect that the Prophet postponed the stoning of al-Ghamidiyyah until the weaning of her child, and the other which omits this part and suggests that she was stoned to death as soon as a man from the Anhar undertook custody of her child. To this al-Zayla'i commented that "It is possible that there were two women from the tribe of Ghamid, one whose punishment of stoning was delayed until the weaning of her child, and the other who was stoned without such a delay. It is also possible that one of them was from the tribe of Ghamid and the other from another tribe but that the narrator made a mistake in reporting, and God Knows Best."13

The various references above to abrogation (naskh) raise methodological questions and warrant a brief discussion.

A basic question arises as to whether abrogation is of any relevance to the issue before us. In answer, it may be noted that only the Hanafis consider it 
relevant, not the majority. The majority, including Imam al-Shafi'i, have viewed the provisions of the Qur'an and Sunnah on the punishment of zina within the context of specification of the general (takhhih al- 'aam), saying that the general provision of the Qur'an has in this instance been specified by the Sunnah. The Qur'an laid down a certain punishment and the Sunnah adjusted it in respect of married persons. The Hanafis have, however, seen this as a case not of specification, but of partial abrogation of the Qur'an by the Sunnah on the analysis that death by stoning is a capital punishment on which the Qur'an is silent, and if the Sunnah validates it over and above the Qur'anic provision of flogging, then the issue involved is one of abrogation rather than mere specification. This seems a sound argument as flogging can logically not be specified by death, which far exceeds flogging and the logical boundaries of 'specification'. Another question is whether the Sunnah can actually abrogate the Qur'an.

Although the majority admit in principle the validity of abrogation of the Qur'an by the Sunnah, many prominent scholars, including Imam al-Shafi'i, have held otherwise, stating that it is the proper role of the Sunnah to explain and supplement the Qur'an, not abrogate it. This is again a sound statement of principle, which Imam al-Shafi'i has explicitly adopted in his exposition on the theory of abrogation. ${ }^{14}$ This would naturally imply that abrogation should not be too readily utilised, that it must be seen as the last resort. The fiqh scholars have consequently shown reluctance in invoking abrogation in order to resolve the discrepancy between the Qur'an and Sunnah on the punishment of zina.

The Hanafis have further added that all the ahadith on the subject of stoning are solitary (Ahad) reports which are not totally devoid of doubt; it would be incorrect to validate death by stoning on the basis of doubtful evidence. Indeed, Imam Abu Hanifah has considered the hadith of al-Ghamidiyyah to be doubtful, meaning it should not be given credibility. ${ }^{15}$ By contrast, the Qur'anic text on the punishment of flogging for zina is perspicuous (muhkam), definitive and conclusive, leaving no room for speculative interpretation. Certainly, Imam alShafi'i's understanding of abrogation is that only the Qur'an can abrogate the Qur'an. Since the Qur'an is the first source of shariah, it is superior in respect of both authority and authenticity to the Sunnah. Hence any incidence of conflict between the definitive text of the Qur'an and Ahad hadith should naturally be determined in favour of the Qur'an. But al-Shafi'i, along with the majority, maintains that the general of the Qur'an has been specified by the Sunnah in respect to zina and married persons.

There is also the report attributed to the second caliph 'Umar, in which he stated that the Qur'anic text on flogging for zina was abrogated by the Qur'an itself. It is thus stated that a verse was revealed as a part of sura al-Ahzab (33), 
which declared that "when a married man or woman commits adultery, stone them to death as a deterrence from God, and God is Most Powerful, Most Wise."

$$
\text { الشيخ والشيخة إذأ زنيا فارجموهما البتة نكالا من الله والله عزيز حكيم }
$$

It is stated that, although this verse did not become part of the Qur'anic text, its ruling did become part of the shariah. The reported addition was not incorporated into the standard text simply because it did not amount to something continuously proven (mutawatir), and anything less than mutawatir cannot, as a rule, become a part of the Qur'an. 'Umar al-Khattab has widely been quoted as having said "had it not been for people saying that 'Umar made an addition to the Qur'an, I would have added this to the Qur'an." The renowned Qur'an commentator, Shihab al-Din al-Alusi (d.1854), however, after related this incident in his Tafsir al-Ma'ani, concluded that the evidence in support of it is doubtful, adding that the prominent Hanafi jurist, Kamal al-Din ibn al-Humim (d.1457), arrived at the same conclusion. Both scholars have also said that the actual wording of the alleged verse falls short of the eloquent style of the Qur'an, besides which the notion that there was an addition to the Qur'an on stoning that God Most High ordered the Prophet to eliminate from the text while retaining its ruling sounds rather imaginary. This is also the position taken by the Kharijites and the Mu'tazilah who have held that, had God willed stoning for zina, He would have made a clear provision in the Qur'an for it. The conclusion is thus drawn that 'Umar's report of the added verse remains doubtful and cannot overrule the clear text on flogging.

The claim that the Companions reached a consensus on 'Umar al-Khattab's version of events has also been questioned, both by Ibn al-Humam and alAlusi. They have stated that it is debatable whether a tacit consensus (al-ijma' al-sukuti) of this kind could present credible evidence in the face of the clear text of the Qur'an. The fact is that by the time of caliph 'Umar, most leading Companions had either lost their lives (in the wars of apostasy etc.) or were away from Madinah. This weakens the claim of general consensus (ijma') in support of 'Umar's version of events, for which there is only 'Umar's word, with other Companions having remained silent concerning it. ${ }^{16}$

Concerning banishment as a supplementary punishment, the Hanafis and the Shia Imamiyyah have held that the punishment of an unmarried person is one hundred lashes only, but if the head of state decides to banish the fornicator, he may do so by way of shariah-oriented policy (siyasah shar'iyyah). They maintain, however, that this is not a requirement. Imam Shafi'i maintained, on the other hand, that banishment for one year was a requirement and an integral part of the prescribed punishment for an unmarried person, be they male or female. 
This was also the position of the Hanbalis and the Zahiriyah. But Imam Malik (d.795) and al-Awza'i (d.774) have exempted women from this ruling based on considerations of public interest (maslahah), so as to prevent further indulgence in corruption. It is also stated that the requirement that a woman may only be banished with the company of a close relative would mean that an innocent person is also condemned to banishment. The Hanafis have further added that the Pious Caliphs, including 'Umar al-Khattab, are on record as having punished zina by unmarried persons with flogging only, without banishment. ${ }^{17}$

\section{Modern Opinion on Stoning (Rajm)}

This section examines the views of Muhammad 'Abduh and his disciple, Muhammad Rashid Rida, in addition to those of Muhammad Abu Zahrah, Mustafa Ahmad al-Zarqa, Yusuf al-Qaradawi, Sheikh 'Ali Gomma, and others on both death by stoning as a punishment for adultery and the meaning of muhsan (lit. guarded person) on whom it is applied.

As already noted, the majority of the leading schools of Islamic law have upheld the validity of stoning for adultery. This position is, however, disputed by the proponents of a minority view, including the Mu'tazilah and Kharijites, who maintain that stoning was the punishment at an early stage before its abrogation by the revelation of the Qur'anic verse al-Nur 24:2 declaring 100 lashes for both men and women adulterers. ${ }^{18}$ As already reviewed, there are also differences of opinion as to how the ruling of the Sunnah on stoning relates to the Qur'an, whether by way of specification (takhsis) or of abrogation (naskh). Current practice in many Muslim countries, however, is dominated by the ruling of the Sunnah on stoning. Twentieth century scholars have reflected further on this and offered additional clarifications and insights.

'Ali Mansur, author of Nizam al-Tajrim wal-'Iqab fil-Islam (1976) and former President of the Constitutional Court of Egypt and Chairman of the Committee on the Harmonisation of Shariah and Law, wrote that "Muhammad Abu Zahrah, who is one of the leading scholars of shariah of this century sent to me in writing his opinion on the subject of stoning where he concluded that the evidence for this punishment was doubtful and it was therefore preferable not to apply it." ${ }^{\prime \prime}$ Mansur added that Abu Zahrah expressed his views at a conference in the Moroccan city of Casablanca on 22 Rabi' al-Awwal 1392AH (6 May 1972). Abu Zahrah's views on this matter have also appeared in his own book, Al-Jarimah wa'l 'Uqubah fi'l-Figh al-Islami: al- 'Uqubah, published in several editions (initially in c.1959), which may be summarised as follows: 
1. There is no disagreement among the jurists and ulama of the four leading schools of Islamic law that the punishment of flogging for zina prescribed in the Qur'an applies to unmarried men and women. The majority (jumhur) have added that a male fornicator is also liable to banishment or imprisonment for a year so that he is not ostracised for what he has done and that, in course of time, the people may forget about it. Imam Malik has held that banishment should not apply to women convicted of zina for fear of immorality and corruption. ${ }^{20}$

2. As for the punishment of stoning for a married person, Abu Zahrah refers to the relevant ahadith, especially those of al-'Asif, of 'Umar al-Khattab (concerning the verse of stoning), Ma'iz and al-Ghamidiyyah. But then he notes that all of these ahadith are solitary; the mere fact that there are several of them does not elevate them to the rank of continuously proven, which status alone would inspire conviction and preclude the possibility of lying and doubt in the transmission of hadith.

3. Abu Zahrah draws attention to the hadith recorded in Sahih al-Bukhari that one of the Followers (tabi'un) asked a leading scholar (mujtahid) among the Companions whether sura al-Nur was revealed before the ahadith on stoning or after. As already noted, the Companion answered that he did not know. The full text of this hadith is as follows:

$$
\begin{aligned}
& \text { حدثني اسحاق كما حدثني خالد عن الشيباني قال :سألت عبد الله ابن أوفى :هل رجم رسول الله }
\end{aligned}
$$

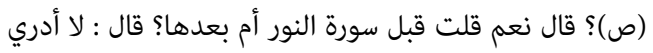

Narrated from Ishaq - from Khalid - from ash-Shaybani: I asked 'Abd Allah Ibn Abi Awfa, "Did God's Messenger carry out the stoning punishment?" He said "Yes." I then asked: "Before the revelation of sura al-Nur or after it?" He replied "I do not know."

Hadith scholars have, however, attempted to resolve the doubt raised in this report by saying that the ahadith of stoning came after the revelation of sura al-Nur, meaning the former abrogate the latter. This is why 'Umar al-Khattab acted on the rulings of these ahadith. This position is seen to be supported by the fact that sura al-Nur was revealed in year four of the Hijrah (or according to some reports, year five or six), while the transmitters of the ahadith on stoning, namely Abu Hurayrah and Ibn 'Abbas, came to Madinah in year seven and nine respectively. But, these individuals may have reported the ahadith from other Companions without actually saying so - hence the question still remains unanswered 
as to the timing of the hadith reports. The issue is then addressed on methodological grounds, as the majority maintain that the general ('aam) does not abrogate the specific (khas), but is itself specified even if the specific is later in time. The general terms of the verse of zina in sura alNur are thus seen as having been specified by the hadith. But the Hanafis, as already noted, do not allow this by means only of a solitary hadith, saying that the hadith in question must be either continuously proven or widely known (mutawatir or mashhur), and the ahadith on stoning do not qualify as either. The Hanafis have also considered the issue as one of abrogation and not specification.

Furthermore, the Hanafis do not follow the hadith of al-'Asif, despite the fact that it has been recorded by four of the Six Compilations of hadith, because the provision of banishment therein is an addition to the Qur' an and this cannot be done by means of a solitary hadith. The Qur'an has made no reference to banishment, and that must prevail over the doubtful addition of a solitary hadith. Although the Hanafis do not consider banishment to be obligatory, they maintain that the head of state is within his rights to combine it with flogging if he deems that this would serve a good purpose. Banishment, in other words, is not a part of the hadd punishment but may be added to it by way of ta'zir. This is also the view of the Imami and Zaydi Shia. The Imams Malik, Shafi'i, Ibn Hanbal, and the Zahiri school have, on the other hand, held that banishment is an integral part of the prescribed punishment on the authority of the hadith of al-'Asif.'

4. At this point, Abu Zahrah relates the views of the Kharijites, some Shia, and Mu'tazillah to the effect that there is no other punishment for zina other than flogging. Had God intended to validate stoning, they argue, the Qur'an would have been explicit about it. Moreover, they further argue that stoning, as the most severe of all punishments, should be proven by decisive evidence from either the Qur'an or hadith mutawatir before being implemented. Although solitary hadith can create obligation and a shariah ruling, they cannot override what is proven by decisive evidence. Added to this is the unresolved doubt expressed by a Companion as to whether the stoning of Ma'iz and al-Ghamidiyyah preceded or succeeded the Qur'anic text. Stoning as a punishment also collapses on the basis of the ruling of a separate hadith, which is also a legal maxim of figh, that doubt suspends the implementation of hudud.

"Ali Mansur then observes that "based on these reasons and the attending doubts concerning the proof of stoning and its severity, the learned author (Abu Zahrah) was not inclined to recommend its 
enforcement. ${ }^{23}$ This is also intimated in Abu Zahrah's own writings some fifteen year previously, which nevertheless stopped short of making a categorical statement on whether enforcement should be suspended. ${ }^{24}$ Abu Zahrah's own analysis, however, contains additional information to the effect that stoning was initially introduced in the Torah, which was applied by the Jews and Christians. There is, in fact, clear confirmation in the Qur'an that the Jews of Madinah were governed by their own scripture:

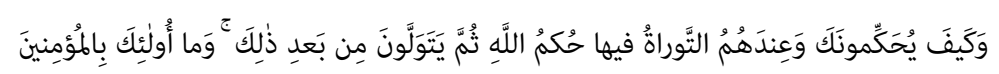

And how do they make you a judge and they have the Torah wherein is God's judgement! Yet they turn away after that! And these are not [true] believers. ${ }^{25}$

Qur'an commentators have identified the occasion of revelation for this verse as follows: a leading Jewish figure resident in Madinah had committed zina and the Jewish community was distressed by the predicament of having him stoned in accordance with the Torah. So they came to the Prophet in the hope of securing a lighter punishment for the accused. The Prophet, however, mentioned the ruling of the Torah to them. ${ }^{26}$

Mohammad Suleman Siddiqi's research leads him to the conclusion that the above verse was revealed to the Prophet as late as year seven of the Hijra, whereas sura al-Nisa' was revealed in year three and sura al-Nur in year five, all of which deal with the punishment of unmarried offenders. With reference to married offenders, the Prophet therefore referred to the Torah, thereby providing stoning for married offenders. Siddiqi also mentions that the case of adultery committed by a man and woman from the Jewish tribe of Khaybar occurred in the first year of the Hijra, immediately after the Prophet's migration to Madinah. ${ }^{27}$

It was probably during the closing months of year five of the Hijra and the beginning of year six that the verses 2-5 of sura al-Nur were revealed. The events between the first Hijra year until the revelation of this verse leave little doubt that the Prophet had implemented the punishment of stoning by reference to the Torah. ${ }^{28}$

'Ali Mansur, who quoted Abu Zahrah's view on this, adds that the prominent Syrian jurist, Mustafa Ahmad al-Zarqa, was present at the same conference and heard Abu Zahrah's views on the subject of stoning: "He too sent his opinion in writing to me in my capacity as Chairman of the then United Arab Republic's Committee for Harmonisation of Shari'ah and Law, wherein he had reached the conclusion that stoning as a punishment for zina should not be enforced, not 
because of the doubt in the authenticity of hadith but because it is quite possible that the Prophet imposed stoning as a ta'zir punishment." Al-Zarqa then added that this was also the opinion of Shaykh Mahmud Shaltut, then Rector of alAzhar. The text of al-Zarqa's letter contained the following:

In my view there is a distinct possibility that the Prophet ordered stoning, in the related incidents by way, not of hadd, but of ta'zir punishment. For he saw under the circumstances that only a strong and decisive stand on this issue could curb the rampant immorality and corruption of the Time of Ignorance (jahiliyyah). Since the lawful government and the ulu al-amr are within their rights to introduce ta'zir punishment in their effort to combat criminality and to secure benefit for the community, it is likely that the Prophet also exercised his authority in this way and introduced stoning as a $t a{ }^{\prime} z i r$ punishment. ${ }^{29}$

Al-Zarqa then referred to the prevailing modern opinion among the ulama that stoning "is a ta'zir punishment, not one of the hudud, and it is as such, a matter for the head of state to apply it in aggravated circumstances. This view also finds support in the Sunnah of the Prophet and the manner he actually applied stoning as a punishment for zina." 30 Zarqa continued that the textuallyprescribed punishment for zina is 100 lashes of the whip. He added further that the shariah made the application of hudud, including in cases of zina, contingent on strict conditions that must be observed in the material aspects of the offence, its evidence and proof. If all these conditions are properly observed, hudud can only be expected to be rarely applied as they will, for the most part, be converted to ta'zir penalties that the qadi determines by reference to the attending conditions of the crime. The presence of any doubt, however slight, will suspend the hadd in question. This is the clear directive of the hadith: "suspend the hudud whenever there is doubt." ${ }^{\prime 31}$

With reference to the proof of zina, Zarqa is of the view that "it is impossible to prove zina except by the confession of its perpetrator," simply because proof by witnesses would require eye-witnessing by four upright persons, which is almost impossible to obtain. Confession by the perpetrator "must also be four times in four different sessions, and when these strict conditions are not met in the proof of zina, the punishment in question, be it lashing or stoning, would be abandoned and recourse had to be made to ta'zir punishment, the type and quantity of which is determined by the ruler/judge in accordance with its attending circumstances." ${ }^{32}$ In the event of retraction of a confession, the prescribed punishment is also abandoned and substituted with a ta'zir punishment.

With reference to the meaning of muhsan, Abu Zahrah observed that there is no clear text to determine that a divorced woman, or a man whose wife has 
died, be classified as muhsan. Somewhat like the musafir (traveler) who is no longer a musafir after returning from his journey, or the sick person (marah) who enjoyed certain concessions under the law until he recovered, so is the case of the muhsan who is no longer a muhsan after the termination of his marriage. There is even a view that the word muhsanah in the Qur'an, as quoted below, means 'virgin women' and not, as is commonly said, 'married women'. This is because virginity is a great disincentive and preventer from zina as it is a means of proving the woman has not been intimately involved with men. How is it then justified to subject a woman who might have lost two great protections against zina, namely virginity and marriage, to heavier punishment? Is it because her previous marriage is still regarded as her protector and, if so, where is the logic in this? Reason would surely tell us that a woman who was once married but is married no longer should not be treated more harshly than a virgin. If anything, the former should be given a lighter punishment, not harsher. Or preferably, the two should be treated equally, and there is nothing in the Qur'an and Sunnah to say otherwise. ${ }^{33}$

Even before Abu Zahrah, Muhammad 'Abduh (d.1905) and his disciple Muhammad Rashid Rida (d.1935) held that the punishment of zina was only applicable to offenders who were parties to a valid marriage at the time of committing the offence: "A muhsan is a person who is protected (physically and morally), in the case of a woman, by her husband, and when there is a separation, or divorce, she no longer qualifies as a muhsanah in the same way as she is no longer a mutazawwijah, or a married woman." As for the offender who had been married but was no longer so, he or she should be punished lightly or equally to that of the unmarried offender. ${ }^{34}$ This they said notwithstanding the majority opinion that it mattered little if the married person had separated or divorced and had no access to his/her spouse for a long time - i.e. that he/she was still a muhsan.

While referring to the views of Muhammad 'Abduh and Rashid Rida, Selim el-Awa, himself an expert and author of important works on Islamic criminal law, concurred with them. ${ }^{35}$

Cheriff Bassiouni also wrote concerning the punishment of zina that the Qur'an provides flogging as the punishment for this offence and not stoning, as is often assumed. Death by stoning "was first imposed by the Prophet during his days in Madinah (620-632 CE), when he applied Jewish law to the Jewish tribes in and around Madinah, and whose laws required such a penalty. In other words, Islam itself does not require stoning, and its use was mistakenly transposed onto Islam." 36

Yusuf al-Qaradawi has forcefully spoken on another aspect of hudud enforcement: that it is a matter for the ruling authorities, not individual Muslims, 
to attempt its implementation. Even if individual Muslims know the perpetrator and are able to enforce the punishment, their role is merely to report the matter to the authorities, not to take the law into their own hands. Doing otherwise would only lead to chaos and confusion. It is not for individuals to cut off the hand of the thief, nor to lash the adulterer, nor to lash the wine drinker, nor to retaliate in the case of murder, and so forth. While some people may think this is expected of them, and thus appoint themselves as "police, judge and enforcement officers," this would be patently erroneous. It is not their role, and they should not take it on themselves. ${ }^{37}$

Al-Qaradawi further adds that, when the government and the ulu al-amr fall short of enforcing the rules of shariah, or when they breach the trust and order of duty entrusted to them, it is for the community to advise their leaders by way of constructive advice (nasihah). Otherwise the people should resort to all lawful means until they succeed in impressing their message on their leaders. But they should also bear in mind the shariah guideline that one should not try to repel an evil with a bigger evil. It is an obligation under such circumstances to take the lesser of two evils. Hence the role of the individual in regard to law enforcement is to assist the honest employees and enforcement officers of the authorities and work with them to apply the law, not to take their place and become law enforcers themselves. ${ }^{38}$

In a fatwa issued with regard to the modern applicability of Islamic corporal punishment, the former Grand Mufti of Egypt, Sheikh Ali Gomaa, observed:

$H u d u d$ have not been implemented in countries such as Egypt for a very long time. This is because the legal conditions for their implementation, which describe specific means for establishing guilt and stipulate the possibility of retracting a confession, are not met. Most of the penal codes of the remainder of the Islamic countries remain silent on the issue of corporal punishment (hudud). This is because our age is one of general uncertainty (shubha), and the Prophet, may the peace and blessings of God be upon him said, 'Suspend the enforcement of corporal punishments when there is doubt.' 39

\section{Conclusion and Recommendations}

- Our enquiry supports the conclusion that the Prophet most likely applied stoning for zina prior to the revelation of sura al-Nur (24:2-5) as a ta'zir punishment to curb widespread immorality and corruption. Yet, the evidence we have examined falls short of clarifying the question of 
whether stoning was applied before or after the revelation of sura al-Nur and its stipulated punishment of 100 lashes.

- Certain questions require clarification and present, in turn, a case for a serious reconsideration of the validity of death by stoning. These are: unresolved doubts about the chronological sequence of the two rulings; whether stoning was applied as a ta'zir; whether or not the Prophet actually took recourse to the Torah; and whether it is correct for the Sunnah to overrule the Qur'an on a capital punishment issue.

- Most leading twentieth-century scholars of shariah have taken the view that enforcement of death by stoning for zina is doubtful. This doubt invokes, in turn, the hadith directive that hudud be suspended when there is doubt.

- Leading ulama who have doubted the continued validity of stoning have further held that the maximum punishment for zina is 100 lashes of the whip for married and unmarried persons alike. All claims and prosecutions of zina that fail to present the textually stipulated proof (four eye-witnesses) reduce zina from a hadd to a ta'zir offence, in turn enabling the trial judge to order a suitable punishment.

- When the Qur'an set the standard of proof for zina at four eye witnesses, the purpose was obviously to set a high moral standard for Muslim individuals - one which cannot be readily enforced, as it is next to impossible for anyone to produce that kind of proof. Yet this aspect of the Qur'an is not duly reflected in the overly punitive approaches of the fiqh manuals and judicial practices of many present-day Muslim countries.

- In trying the $t a$ 'zir offence, it would be in order for the judge to take into consideration all relevant factors, including the nature of the relationship (if any) between parties, use or otherwise of force, trickery and temptation, age, whether a first time offender or a recidivist, indications of repentance and remorse, social mischief, lessons to be had for others, and so forth.

\section{Notes}

* Mohammad Hashim Kamali, Founding CEO of IAIS Malaysia, graduated from Kabul University, and then obtained his $\mathrm{PhD}$ in Islamic and Middle Eastern Law at the University of London in 1976. He served as Professor of Islamic Law and Jurisprudence at the International Islamic University Malaysia (1985-2004), then Dean of the International Institute of Islamic Thought and Civilization 
(ISTAC) from 2004-2006. He was Asst Professor at McGill University's Institute of Islamic Studies; Visiting Professor at Capital University, Ohio; and the Wissenschaftskolleg, Berlin. He was a member of the Constitution Review Commission of Afghanistan (2003), and a UN shariah expert on the constitutions of Iraq, the Maldives and Somalia (2004-2005). He has published over 200 academic articles and 35 books. He can be contacted at ceo@iais.org.my.

1. Cf., al-Mawsū'ah al-Fiqhiyyah, vol. 14, 21; Shi'i law records similar positions and a roughly parallel discourse over the issues involved. See for details, Muhaqqiq al-Hilli, Mokhtasar-e Nafi', tr. in Persian (from Arabic) by Muhamad Taqui Danish-pazhoh (Tehran: Bongah-e Tarjomah wa Nashr-e Kitab, 1964/1343), 351f.

2. Abu'l-Walid Muhammad Ibn Rushd Al-Qurtubi (known as Ibn Rushd al-Hafid), Bidāyat al-Mujtahid wa Nihāyat al-Muqtașid (Lahore: Faran Academy, n.d.), II, 325.

3. Al-Jaziri, al-Fiqh 'al'l-Madhāhib, 1211.

4. Mohammad Suleman Siddiqi, "The Concept of Hudud and its Significance," Islamic Culture 55 (1981), 198. Sayyid Abul A'la Maududi, Tafhim al-Qur'an (Delhi, 1963), Vol III, 321-3.

5. Muhammad b. Ali al-Shawkani, Nayl al-Awtār Sharh Muntaqā al-Akhbār (Cairo: Mustafa al-Babi al-Halabi, n.d.), vol. VII, 97-100; see also for these and other ahādith Jamāl al-Din a1-Zayla'i, Nașb al-Rāyah li-Ahädith al-Hidayah (Beirut: Al-Maktab al-Islami, 1393 H), $2^{\text {nd }}$ edn, vol. III, 328-83; al Sarakhsi, AlMabsūt vol. IX, 36ff.

6. Al-Zayla'i, Nasb al-Rāyah, vol. III, 329.

7. Al-Sarakhsi, Al-Mabsüt, vol. IX, 43-4.

8. Shihāb al-Din Mahamūd al-Alūlsi, Rūḥ al-Ma 'āni fi Tafsir aI-Qur'ān al-'Azim (Cairo: Idārah al-Tabā' ah al-Muniriyyah, 1985/1405), $4^{\text {th }}$ edn, vol. XVIII, 79.

9. Muhammad Muhsin Khan, The Translation of the Meaning of Sahīh al-Bukhärī (Lahore: Kazi Publications 1983), 6 ${ }^{\text {th }}$ edn. vol. VIII, 526 Hadith No. 803.

10. Al-Shawkani, Nayl al-Awtār, vol. VII, 100.

11. Jamal al-Din al-Zayla'i, Tabyīn al-Haqā iq fi Sharh Kanz ai-Daqā'iq (Egypt, Bulaq: Al-Matba'ah al-Amiriyyah, 1313H), vol. III, 174.

12. Cf. 'Ali Mansūr, Nizām al-Tajrim wa'l- 'Iqāb fil-Islam (Madinah al-Munawwarah: Mu'assasah al Zahrā, 1976/1396), 175 ff.

13. See for details Al-Zayla'i, Tabyin, vol. III, 175; Manșūr, Nizāam al-Tajrìm, 176.

14. For further detail on naskh and the differences of madhähib therein see Mohammad. H. Kamali, Principles of Islamic Jurisprudence (Cambridge: Islamic Texts Society, 2003), 202-28.

15. Cf. Manșūr, Nizām al-Tajrim, 172.

16. Al-Alūsi, Rūḥ al-Ma'āni, vol. XVIII, 79.

17. A1-Sarakhsi, A1-Mabṣūt, vol. IX, 44-5; Ali Manșūr, Nizām. at-Tajrìm, at 181-2.

18. Cf., Al-Jaziri, al-Fiqh 'ala'-Madhahib, 1179.

19. Manșūr, Niẓām al-Tajrīm, 181-2.

20. Ibid., 182-3; Abu Zahrah, Al-'Uqūbah, 100ff.

21. Sahịh al Bukhari, Muhsin Khan’s trans. vol. VII, 527, Hadith 804; Abu Zahrah, Al-'Uqūbah, 101 Manșūr, Nizām, 182-3. 
22. Abū Zahrah, Ibid, 101-2; 'Awdah, al-Tashri' a1-Jinā 'i, vol. II, 380. See also alSarakhsi, A1-Mabsüt, vol. IX, 45.

23. Manșūr, Nizām al-Tajrim, 182.

24. Abū Zahrah, al-'Uqūbah, 98-105.

25. Q. Surah al-Mā'idah, 5:43.

26. Abu Zahrah, al-'Uqubah, 104.

27. Suleman Siddiqi, "The Concept of Hudud," 191-207 at 195.

28. Ibid., 197.

29. Mansur, Nizām al-Tajrīm, 182-3.

30. Mustafa Ahmad al-Zarqa, al-Madkhal al-Fiqhi al- 'Amm: Ikhraj Jadid fi'l-Tartib wa'l-Tabwib wa'l Ziyadat (Damascus: Dar al-Qalam, first ed., 1991/1418), vol. 1, 290 .,

31. Ibid., 283.

32. Al-Zarqa, al-Madkhal, vol.1, 291.

33. Abu Zahrah, al-Uqübah, 103-4.

34. Muhammad Rashid Riḍā. Tafsīr al-Manār (Cairo: Matba'ah al-Manar, $1953 / 1373 H), 4^{\text {th }}$ edn., vol. V, 25.

35. El-Awa, Punishment, 19.

36. Cheriff Bassiouni, The Shari' $a$ and Islamic Criminal Justice, 136.

37. Yusuf al-Qaradawi, Hawla Qadaya al-Islam wa'l-'Asr (Cairo: Maktabah Wahbah, 2006/1427), $3^{\text {rd }}$ edn, 96.

38. Ibid., 96-7.

39. http://www.virtualmosque.com/islam-studies/faqs-and-fatwas/review-ofgomaas-responding-from-the-tradition/ (Accessed on: 2 October 2015). See also One Hundred Contemporary Fatwas by the Grand Mufti of Egypt, Sheikh Ali Gomaa (Louisville, KY: Fons Vitae, ), 2011. 